\title{
The database of odor responses (DoOR) - Mapping the fruit fly's odor space
}

\author{
Martin Strauch \\ From 1st International Workshop on Odor Spaces \\ Hannover, Germany. 4-7 September 2013
}

The database of odor responses (DoOR) is a repository for odor response measurements in the fruit fly Drosophila melanogaster. Olfactory receptors have broad, overlapping response spectra, and olfactory coding relies on activity patterns across the entire receptor array. It is therefore of interest to record receptor responses to a large set of odorant molecules, as opposed to only finding the respective best ligand.

The fruit fly has since long served as a model organism, resulting in a large number of odor response measurements that are available in the literature. Going beyond archiving the (odorant $\mathrm{x}$ receptor) response matrices from a growing number of studies on Drosophila olfaction, DoOR also provides a consensus matrix that integrates data from different studies using different techniques [1]. Such data integration leads to a larger odor response space than available from any single study.

Apart from encyclopedic applications, DoOR can be used e.g. to estimate odor (dis)similarity as "perceived" by Drosophila, and it has already served as realistic input data for a modelling study on odor processing in the antennal lobe [2]. DoOR is available both as a web-based GUI and as package for the $\mathrm{R}$ platform [3].

Published: 16 April 2014

\section{References}

1. Galizia CG, Münch $D$, Strauch M, Nissler A, Ma S: Integrating heterogeneous odor response data into a common response model: A DoOR to the complete olfactome. Chem Senses 2010, 35:551-63.

2. Proske JH, Wittmann M, Galizia CG: Olfactory sensor processing in neural networks: lessons from modeling the fruit fly antennal lobe. Front Neuroeng 2012, 5:2.

3. [http://neuro.uni-konstanz.de/DoOR/].

\section{doi:10.1186/2044-7248-3-S1-021}

Cite this article as: Strauch: The database of odor responses (DoOR) Mapping the fruit fly's odor space. Flavour 2014 3(Suppl 1):O21.

Submit your next manuscript to BioMed Central and take full advantage of:

- Convenient online submission

- Thorough peer review

- No space constraints or color figure charges

- Immediate publication on acceptance

- Inclusion in PubMed, CAS, Scopus and Google Scholar

- Research which is freely available for redistribution 